\title{
Variables associated with the risk of colorectal adenomas in asymptomatic patients with a family history of colorectal cancer
}

\author{
P Gaglia, W S Atkin, S Whitelaw, I C Talbot, C B Williams, J M A Northover, \\ $S$ V Hodgson
}

\begin{abstract}
The results of screening individuals referred to the Family Cancer Clinic at St Mark's Hospital from 1986 are presented. Colonoscopy was performed in 644 asymptomatic individuals (from 436 families) with a family history of colorectal cancer. Sixty nine $(15 \cdot 8 \%)$ of the families fulfilled the Amsterdam criteria for the hereditary non-polyposis colorectal cancer syndromes (HNPCC). Seven cases of colorectal cancer were diagnosed at an average age of $\mathbf{4 9}$ years; six at Dukes's stage $A$ and one at stage $C$, four in subjects from Amsterdam criteria families. One hundred and forty four $(22.4 \%)$ subjects had one or more adenomas. The prevalence of adenomas in the subjects from Amsterdam criteria families was 34 of 127 $(26.8 \%)$ compared with 110 of $517(21 \cdot 3 \%)$ in those from other families; the age and sex adjusted odds ratio (OR) was 1.76 $(p=0 \cdot 02)$. Factors influencing the prevalence of adenomas in screened individuals were evaluated. Multivariate analysis showed that independent variables significantly related to the risk of adenomas were: age $(p<0.0001)$, sex $(p=0.0002)$, and the number of generations $(\geqslant 2 v 1)$ of relatives affected by either colorectal cancer or adenomas $(p=0 \cdot 0006)$. The latter variable was more highly predictive of the probability of finding an adenoma at colonoscopy than a family history of two generations with cancer only $(p=0 \cdot 056)$. The OR of having colorectal adenomas increased with age, by about twofold for each decade, and was twice as high in men than women, and in subjects with two or more generations relative to those with one generation affected by colorectal cancer or adenomas. Six of seven patients with cancer and 46 of $144(31.9 \%)$ with adenomas had lesions proximal to the splenic flexure only. The proportion of individuals with proximal adenomas only was $\mathbf{4 7} \cdot 1 \%$ in Amsterdam criteria families and $27 \cdot 3 \%$ in the others $(p=0 \cdot 03)$. These findings support the view that colonoscopy rather than sigmoidoscopy is the method of choice for screening high risk groups.

(Gut 1995; 36: 385-390)
\end{abstract}

Keywords: hereditory non-polyposis colorectal cancer, screening, adenomas.
There are approximately 20000 deaths from colorectal cancer annually in England and Wales. The lifetime incidence for colorectal cancer has been estimated to be in 1 in 27 for both men and women in England and Wales. ${ }^{1}$ The ratio of new cases to deaths has not changed significantly in recent years, since the results of treatment for advanced disease are still poor. Thus, earlier detection probably offers the best hope for improving outcome.

Most colorectal cancers are thought to arise from adenomatous polyps. ${ }^{23}$ Moreover, it has been reported that their detection and removal by endoscopic screening could reduce the incidence of colorectal cancer. ${ }^{4}$ Criteria for the selection of individuals for endoscopic surveillance very widely, but a family history of colorectal cancer has been used by other groups for selection for screening. 56

The importance of an inherited predisposition in colorectal cancer is a matter of some debate. Familial adenomatous polyposis (FAP) probably causes only about $1 \%$ of all cases of colorectal cancer. Single gene abnormalities leading to the hereditary non-polyposis colorectal cancer syndromes (HNPCC) may underlie up to $5-10 \%$ of colorectal cancer. ${ }^{78}$ Inherited genetic factors may contribute to the development of colorectal cancer in other cases. Familial clustering of cancer is well recognised, and an increased overall relative risk of dying from colorectal cancer of about threefold has been demonstrated in the first degree relatives of unselected colorectal cancer patients. ${ }^{9} 10$

Such evidence has led to widespread calls for screening in those with a positive family history. Audit of such screening programmes is critical. This paper describes data from colonoscopy screening in a selected population of individuals with a family history of colorectal cancer referred to the Family Cancer Clinic, Imperial Cancer Research Fund, St Mark's Hospital. The evaluation of the predictive value of factors (age, sex, and the extent of the family history) in respect of the prevalence of adenomas has been carried out. This is, of course, based on the supposition that cancers in subjects with an increased genetic risk for colorectal cancer arise in pre-existing adenomas. Only long term follow up of this cohort of patients can elucidate this.

Patients and methods

The Family Cancer Clinic started in 1986 for 
the counselling and selective screening of individuals with a family history of colorectal cancer. Families with FAP are seen in a separate clinic and are not included in this series. In the period 1986-92, 1283 people were seen. Referrals included those from general practitioners $(27 \%)$, from consultants $(19 \%)$, from other registries $(2 \%)$, members of families already ascertained (25\%), and self referrals $(27 \%)$. According to a protocol drawn up by Slack et al, ${ }^{11}$ using data from Lovett's series, ${ }^{9}$ individuals with an estimated risk of dying of colorectal cancer of 1 in 10 or greater were offered surveillance by colonoscopy on a five yearly basis from the age of 25 years, increasing to three yearly if colorectal adenomas were detected. These included people with two or more first degree relatives with colorectal cancer, or one first degree relative affected under the age of 45 years, or a family history of more than two generations affected by colorectal cancer. Some individuals, including those with a two generation family history of colorectal cancer or those from families in which extracolonic cancers had occurred in addition to a family history of colorectal cancer, and others who were excessively anxious, were offered screening even if they did not fulfil the usual screening criteria. In addition, some people were offered screening by colonoscopy when a first degree relative, usually a parent, had been screened in our clinic because of their family history of colorectal cancer, and had been found to have colorectal adenomas (that is, there was a two generation history of colorectal cancer or adenomas). Where colonoscopic surveillance was not offered, screening for faecal occult blood was arranged once a year. At total colonoscopy, all polyps detected were removed and sent for pathological examination.

We included in our study asymptomatic subjects who were offered colonoscopic screening and had neither symptoms relatable to colorectal disorders nor a previous diagnosis of colorectal neoplasia or inflammatory bowel disease. Six hundred and fifty one individuals fulfilled these criteria. Seven declined the offer of colonoscopy (compliance rate $=99 \%$ ), so 644 individuals were available for study.

For each of these individuals, information was obtained at interview about age, the number (and relationship) of relatives affected by colorectal cancer or adenomas, the number of generations in the family affected by colorectal cancer or adenomas, and the age at onset of colorectal cancer in their relatives. Family history was ascertained for at least three generations, and where possible verified from histological reports, death certificates, or physician's reports.

For the purposes of family classification, we followed the Amsterdam criteria for the definition of the HNPCC syndrome as follows: (1) three or more relatives with colorectal cancer, (2) one of the three affected relatives is first degree relative of the other two, (3) cases extend over two or more generations, and (4) one or more cases were diagnosed before 50 years of age. ${ }^{12}$
A multivariate analysis was performed to assess the association between family history variables (Table III) and the risk of adenomas or cancer using a forward stepwise logistic regression (BMDP-LR Computing Facility, UCLA). ${ }^{13}$ A significance level of $p<0.05$ was used for the inclusion of a variable in the model.

In the multivariate analysis the family history variables were coded as shown in Table III. Age was entered either as a continuous or categorical variable (with categories 25-34, $35-44,45-54, \geqslant 55$ years). The results were similar and only those using categorical age are presented.

\section{Results}

The 644 individuals in the study were from 436 families. The age at colonoscopy ranged from 25 to 77 years (median 41 years). Two hundred and sixty five $(41 \cdot 1 \%)$ subjects were male; the percentage of males was similar in each age category (range $39 \cdot 5-42 \cdot 8 \%$ ). Four hundred and fifty nine $(71 \cdot 3 \%)$ individuals from 355 families had relatives affected by colorectal cancer; $185(29 \cdot 7 \%)$ from 81 families had additional relatives known to have colonic adenomas.

One hundred and twenty seven (19.7\%) individuals belonged to 69 families who fulfilled the Amsterdam criteria for HNPCC. A further 245 had either two or more first degree relatives affected, or a first degree relative diagnosed with colorectal cancer aged $\leqslant 45$ years, or two or more generations affected. Of the remaining 272 subjects, 63 had only second degree relatives affected by colorectal cancer (49 had two or more second degree relatives, and 14 had a first degree relative or second degree relative with adenomas or extracolonic cancers found in the cancer family syndrome), and 209 had one first degree relative diagnosed $>45$ years (in 24 the first degree relative was affected before 50 years of age, 59 had two or more affected second degree relatives, 77 had one second degree relative, and 49 had a first degree relative or second degree relative with adenomas or extracolonic cancers).

\section{PATHOLOGICAL FINDINGS}

Polyps were detected in $173(26.9 \%)$ screened subjects (Table I). One or more adenomas were found in $144(22.4 \%)$ subjects, and 21 of these had synchronous metaplastic polyps. Twenty nine $(4 \cdot 5 \%)$ patients had metaplastic polyps only.

Of 144 subjects with adenomas, seven $(4.9 \%)$ had six or more adenomas (range 6-300). These multiple adenomas were more frequent in patients from Amsterdam criteria families than from other families $(11.8 \%$ and $2 \cdot 7 \%$ respectively; $p=0.03$ ). One 50 year old woman with a pedigree consistent with HNPCC was found on colonoscopy to have about 300 adenomas, but there were none in the rectum. Despite this, these findings were consistent with the diagnosis of familial adenomatous polyposis. None of her affected 
TABLE I Colonoscopy findings in 144 of 644 (22.4\%) subjects found to have adenomatous polyps at screening ${ }^{\star}$

\begin{tabular}{|c|c|c|c|c|}
\hline $\begin{array}{l}\text { Pathological features in } \\
\text { patients with adenomas }\end{array}$ & $\begin{array}{l}\text { All patients } \\
(n=144) \\
\text { No }(\%)\end{array}$ & $\begin{array}{l}\text { HNPCC† } \\
(n=34) \\
\text { No (\%) }\end{array}$ & $\begin{array}{l}\text { Non-HNPCC } \\
(n=110) \\
\text { No }(\%)\end{array}$ & $P S$ \\
\hline $\begin{array}{l}\text { Synchronous metaplastic polyps } \\
\text { Multiple }(\geqslant 5) \text { adenomas } \\
\text { Dysplasia (moderate or severe) } \\
\text { Large }(\geqslant 10 \mathrm{~mm} \text { ) adenomas } \\
\text { Villous or tubulovillous adenomas } \\
\text { Adenomas only proximal to the splenic flexure } \\
\text { Cancers in/with adenomas } \\
\text { Significant findings (villous/tubulovillous, } \\
\text { or large, or moderately or severely dysplastic/ } \\
\text { malignant adenomas) } \\
\text { Single diminutive }(<5 \mathrm{~mm} \text { ) adenoma }\end{array}$ & $\begin{array}{c}21(14.6) \\
7(4.9) \\
20(13.5) \\
18(12.5) \\
15(10.5) \\
46(31.9) \\
7(4.9)\end{array}$ & $\begin{array}{r}1(2 \cdot 9) \\
4(11 \cdot 8) \\
5(14 \cdot 7) \\
6(17 \cdot 6) \\
4(11 \cdot 8) \\
16(47 \cdot 1) \\
4(11 \cdot 8)\end{array}$ & $\begin{array}{c}20(18 \cdot 2) \\
3(2 \cdot 7) \\
15(13 \cdot 9) \\
12(10 \cdot 9) \\
11(10 \cdot 0) \\
30(27 \cdot 3) \\
3(2 \cdot 7)\end{array}$ & $\begin{array}{l}0.04 \\
0.03 \\
\text { NS } \\
\text { NS } \\
\text { NS } \\
0.03 \\
0.03\end{array}$ \\
\hline
\end{tabular}

HNPCC $=$ hereditary non-polyposis colorectal cancer.

$\star 29(4 \cdot 5 \%)$ had metaplastic polyps only; +HNPCC/non-HNPCC $=$ patients from families which fulfilled/did not fulfil the Amsterdam criteria; $¥$ HNPCC $v$ non-HNPCC (Pearson $\chi^{2}$ test);

§Male $v$ female sex (Pearson $\chi^{2}$ test); NS = not significant $(p>0.05)$.

TABLE II Odds ratios (OR) 95\% confidence intervals (CI) for adenomas by age and sex

\begin{tabular}{|c|c|c|c|c|}
\hline Variable & Category & $\begin{array}{l}\text { Screened } \\
\text { subjects }\end{array}$ & $\begin{array}{l}\text { Patients with } \\
\text { adenomas }\end{array}$ & OR $(95 \% C I)$ \\
\hline $\begin{array}{l}\text { Age } \\
\chi^{2} \text { tren } \\
\text { (p value }\end{array}$ & $\begin{aligned} & 25-34^{\star} \\
& 35-44 \\
& 45-54 \\
\geqslant & 55 \\
\text { d } & \end{aligned}$ & $\begin{array}{r}179 \\
215 \\
157 \\
93\end{array}$ & $\begin{array}{l}16(8 \cdot 9 \%) \\
40(18 \cdot 6 \%) \\
46(29 \cdot 3 \%) \\
42(45 \cdot 2 \%)\end{array}$ & $\begin{array}{l}1 \\
2 \cdot 33(1 \cdot 25,4 \cdot 32) \\
4 \cdot 22(2 \cdot 27,7 \cdot 84) \\
8 \cdot 39(4 \cdot 35,16 \cdot 19) \\
51 \cdot 8 \\
(0 \cdot 0001)\end{array}$ \\
\hline $\begin{array}{l}\text { Sex } \\
\qquad \chi^{2} \\
\quad(p \text { value }\end{array}$ & $\begin{array}{l}\text { Women } \\
\text { Men }\end{array}$ & $\begin{array}{l}379 \\
265\end{array}$ & $\begin{array}{l}65(17 \cdot 2 \%) \\
79(30.9 \%)\end{array}$ & $\begin{array}{l}1 \\
2 \cdot 05(1 \cdot 41,2 \cdot 99) \\
14 \cdot 2 \\
(0 \cdot 0002)\end{array}$ \\
\hline
\end{tabular}

$\star$ Reference category.

relatives had the familial adenomatous polyposis phenotype.

Forty six subjects with adenomas (31.9\%) had lesions proximal to the splenic flexure only. There was a significant difference in the proportion of right sided adenomas between patients with adenomas from Amsterdam criteria families and from other families $(47 \cdot 1 \%$ and $27 \cdot 3 \%$ respectively; $p=0.03$ ), whereas no significant difference was found between males and females $(30.4 \%$ and $33.8 \%$ respectively).

Fifty nine $(41.0 \%)$ subjects with adenomas had only a single diminutive $(<5 \mathrm{~mm})$ adenoma $(32.9 \%$ men and $50 \cdot 8 \%$ women, $\mathrm{p}=0.03)$.

Thirty nine $(27 \cdot 1 \%)$ adenoma patients had an adenoma which was large $(\geqslant 10 \mathrm{~mm})$, or tubulovillous/villous, or moderately/severely dysplastic, or malignant. The frequency of these unfavourable pathological features was higher in men than in women $(31.6 \%$ and $21.5 \%$ respectively) and in Amsterdam criteria than in other families $(35.3 \% v 24.5 \%)$ but the numbers were too small to reach significance.

Seven cancers (five arising in adenomas, two with synchronous adenomas) were identified; six were Dukes's stage A and one Dukes's stage $C$. The average age at diagnosis was 49 years (range 34-63 years); three patients were male. Four patients (two men) belonged to an Amsterdam criteria family, but three did not. All the cancers but one (in a 63 year old woman) were proximal to the splenic flexure; none of these cases had distal adenomas.

\section{ADENOMA PREVALENCE AND AGE, SEX, AND}

FAMILY HISTORY VARIABLES

The prevalence of adenomas increased with age (Table II). It was less than $10 \%$ in those under 35 years and rose to over $40 \%$ from 55 years, with an increasing odds ratio (OR) of approximately twofold for each decade $(p<0.0001)$. The prevalence of adenomas was about twofold greater in males than in females $(\mathrm{OR}=2 \cdot 05, \mathrm{p}=0.0002)$.

We took eight family history variables and examined the age and sex adjusted ORs of having adenomas or cancer for each (Table III). After adjustment for age and sex, the most significant indicator of the risk of having adenomas was the number of generations in the whole family affected by either colorectal cancer or adenomas (OR for two or more generations $=2 \cdot 16, \mathrm{p}=0 \cdot 0006)$, followed by the pedigree type (OR for Amsterdam criteria families $v$ other families $=1 \cdot 76, p=0 \cdot 02$ ). None of the other variables examined reached

TABLE III Age and sex adjusted odds ratios (OR) 95\% confidence intervals (CI) for adenomas (Ads) by family history variables

\begin{tabular}{|c|c|c|c|c|c|}
\hline Variable & Category & $\begin{array}{l}\text { Screened } \\
\text { subjects }\end{array}$ & $\begin{array}{l}\text { Subjects } \\
\text { with Ads } \\
\text { No }(\%)\end{array}$ & OR $(95 \% C I)$ & $x^{2}$ \\
\hline No of relatives affected by CRC & $\begin{array}{l}1^{\star} \\
2 \\
3 \\
\geqslant 4\end{array}$ & $\begin{array}{l}148 \\
231 \\
138 \\
127\end{array}$ & $\begin{array}{l}32(21 \cdot 6) \\
47(20 \cdot 3) \\
38(27 \cdot 6) \\
27(21 \cdot 2)\end{array}$ & $\begin{array}{l}1 \\
0.78(0.46,1.35) \\
1.27(0.72,2.27) \\
0.90(0.49,1.66)\end{array}$ & $\begin{array}{l}0 \cdot 10 \dagger \\
(0 \cdot 75)\end{array}$ \\
\hline No of FDRs affected by CRC & $\begin{array}{l}0^{\star} \\
1 \\
2 \\
\geqslant 3\end{array}$ & $\begin{array}{r}83 \\
412 \\
128 \\
21\end{array}$ & $\begin{array}{l}16(19 \cdot 3) \\
90(21 \cdot 8) \\
30(23 \cdot 4) \\
8(30 \cdot 1)\end{array}$ & $\begin{array}{l}1 \\
0.91(0.49,1.71) \\
0.71(0.34,1.50) \\
1.28(0.42,3.94)\end{array}$ & $\begin{array}{c}0.16 \dagger \\
(0.69)\end{array}$ \\
\hline No of generations affected by CRC & $\geqslant 2$ & $\begin{array}{l}254 \\
390\end{array}$ & $\begin{array}{l}47(18 \cdot 5) \\
97(24 \cdot 9)\end{array}$ & $1.49(0.99,2 \cdot 26)$ & $\begin{array}{l}3 \cdot 66 \\
(0 \cdot 056)\end{array}$ \\
\hline No of relatives affected by CRC or Ads & $\begin{array}{l}1^{\star} \\
2 \\
3 \\
\geqslant 4\end{array}$ & $\begin{array}{l}114 \\
202 \\
141 \\
187\end{array}$ & $\begin{array}{l}18(12 \cdot 5) \\
42(20 \cdot 8) \\
41(29 \cdot 1) \\
43(23 \cdot 0)\end{array}$ & $\begin{array}{l}1.21(0.63,2.29) \\
2.03(1.05,3.92) \\
1.53(0.81,2.91)\end{array}$ & $\begin{array}{c}2 \cdot 86 \dagger \\
(0 \cdot 09)\end{array}$ \\
\hline No of FDRs affected by CRC or Ads & $\begin{array}{l}0^{\star} \\
1 \\
2 \\
\geqslant 3\end{array}$ & $\begin{array}{r}32 \\
399 \\
163 \\
50\end{array}$ & $\begin{array}{l}7(21 \cdot 9) \\
80(20 \cdot 1) \\
33(20 \cdot 2) \\
24(48 \cdot 0)\end{array}$ & $\begin{array}{l}1 \\
0.97(0.39,2 \cdot 41) \\
0 \cdot 77(0.29,2 \cdot 01) \\
2 \cdot 34(0.81,6.75)\end{array}$ & $\begin{array}{l}2 \cdot 04 \dagger \\
(0 \cdot 15)\end{array}$ \\
\hline No of generations affected by CRC or Ads & $\geqslant 2$ & $\begin{array}{l}213 \\
431\end{array}$ & $\begin{array}{r}32(15 \cdot 0) \\
112(30 \cdot 0)\end{array}$ & $2 \cdot 16(1 \cdot 37,3 \cdot 43)$ & $\begin{array}{l}11 \cdot 66 \\
(0.0006)\end{array}$ \\
\hline Pedigree & $\begin{array}{l}\text { Non-HNPCC }{ }^{\star} \ddagger \\
\text { HNPCC }^{\wedge}\end{array}$ & $\begin{array}{l}517 \\
127\end{array}$ & $\begin{array}{r}110(21 \cdot 3) \\
34(26 \cdot 8)\end{array}$ & $1 \cdot 76(1 \cdot 08,2 \cdot 86)$ & $\begin{array}{l}5 \cdot 08 \\
(0.02)\end{array}$ \\
\hline $\begin{array}{l}\text { No of relatives with early diagnosis } \\
(\leqslant 50 \mathrm{y}) \text { of } \mathrm{CRC}\end{array}$ & $\geqslant 1$ & $\begin{array}{l}305 \\
339\end{array}$ & $\begin{array}{l}79(25 \cdot 9) \\
65(19 \cdot 2)\end{array}$ & $0.96(0.64,1.44)$ & $\begin{array}{l}0.04 \\
(0 \cdot 84)\end{array}$ \\
\hline
\end{tabular}


TABLE IV Neoplasia detection rate by family history

\begin{tabular}{|c|c|c|c|c|}
\hline & \multirow{2}{*}{$\begin{array}{l}\text { No (\%) } \\
\text { of total } \\
\text { screened } \\
\text { subjects }\end{array}$} & \multirow{2}{*}{$\begin{array}{l}\text { No (\%) } \\
\text { patients } \\
\text { with } \\
\text { adenomas }\end{array}$} & \multicolumn{2}{|c|}{$\begin{array}{l}\text { Proportion of total neoplasia } \\
\text { detected if screening had only } \\
\text { been performed in the group } \\
\text { considered }\end{array}$} \\
\hline & & & Adenomas & Cancers \\
\hline \multirow{2}{*}{$\begin{array}{l}\mathrm{HNPCC}^{\star} \\
\geqslant 2 \text { Generations affected by CRC alone } \\
\geqslant 2 \text { Generations affected by CRC or } \\
\text { adenomas }\end{array}$} & $\begin{array}{l}217(19 \cdot 7) \\
390(60 \cdot 6)\end{array}$ & $\begin{array}{l}34(26 \cdot 8) \\
97(24.9)\end{array}$ & $\begin{array}{l}34 / 144(23 \cdot 6 \%) \\
97 / 144(67 \cdot 4 \%)\end{array}$ & $\begin{array}{l}4 / 7 \\
5 / 7\end{array}$ \\
\hline & $431(66 \cdot 9)$ & $112(30 \cdot 0)$ & $112 / 144(77 \cdot 8 \%)$ & $7 / 7$ \\
\hline
\end{tabular}

HNPCC $=$ hereditary non-polyposis colorectal cancer; $\mathrm{CRC}=$ colorectal cancer

${ }^{\star} \mathrm{HNPCC}=$ patients from families which fulfilled the Amsterdam criteria.

statistical significance, although a borderline significantly increased risk $(p=0.056)$ was found when two or more generations of relatives with colorectal cancer were present $(\mathrm{OR}=1 \cdot 49$; $95 \%$ confidence interval: $0 \cdot 99,2 \cdot 26$ ).

In individuals from families who fulfilled the Amsterdam criteria for HNPCC (127 individuals, $19.7 \%$ of those screened; adenoma prevalence $=26 \cdot 8 \%$ ), $23 \cdot 6 \%$ of adenomas and four of seven of cancers were detected (Table IV). Individuals with two or more generations affected by colorectal cancer (390 individuals, $60.6 \%$ of the screened population; adenoma prevalence $=24.9 \%$ ), 97 of 144 of all adenomas $(67.4 \%)$ and five of seven cancers were identified. However, in subjects with a history of two or more generations affected by colorectal cancer or adenomas (431 individuals, $66.9 \%$ of those screened; adenoma prevalence $=30 \cdot 0 \%$ ), $77 \cdot 8 \%$ of adenomas and all the seven cancers were identified. Sixty eight per cent of the relatives known to have adenomas were diagnosed by the screening process itself.

The results of the multivariate analysis are shown in Table V. Age, sex, and all the eight family history variables were considered. The variables selected by the procedure to enter the model were (in order of entry): age $(p<0.0001)$, sex $(p=0.0002)$, and the number of generations in the family affected by either colorectal cancer or adenomas $(p=0.0006)$. We also examined the interaction between the number of relatives and the number of generations affected in order to study whether the significance of the latter variable was explained by differences in the number of affected relatives. The results showed a significant increase in risk from the reference category 'only one relative affected with colorectal cancer' to 'two affected relatives in one generation' $(\mathrm{OR}=0 \cdot 80)$, 'three affected relatives in one generation' $(\mathrm{OR}=0.40)$ compared with 'two affected relatives in two generations' $(O R=1.46)$ and 'three plus affected relatives in two plus generations' $(\mathrm{OR}=1 \cdot 97)$. The test for trend among these categories was significant $(p=0.001)$, confirming the importance of the effect of number of generations involved, even after accounting for the effect of number of relatives.

For a given age group (except the youngest), the presence of one 'unfavourable' factor, either male sex or two or more generations affected by colorectal cancer or adenomas about doubled the risk of finding adenomas, whereas the presence of both increased the risk about fourfold (Table VI).

\section{Discussion}

The policy of the Family Cancer Clinic was to offer colonoscopy to those individuals with a family history consistent with an estimated risk to the consultant of one in 10 or greater of dying of colorectal cancer, according to $\mathrm{Dr}$ Slack's protocol. ${ }^{11}$ In practice the criteria for selection were widened considerably and the extent of a family history of colorectal cancer in the cohort under study was very variable.

The overall prevalence of colorectal adenomas in this colonoscopic series was $22 \cdot 4 \%$. This compares with $12-27 \%$ in other series of patients with at least one first degree relative with colorectal cancer, ${ }^{17-23}$ although there was a considerable variation in the ages of the subjects studied. There have been few colonoscopic studies performed in unselected asymptomatic individuals without a family history of colorectal cancer. ${ }^{14-1620}$ In the present series, $16.6 \%$ of subjects under 50 years of age had adenomas, whereas Guillem found no adenomas in the individuals less than 50 years included in the control group of his study. ${ }^{20} \mathrm{In}$ the present series, the prevalence of adenomas in the 50-59 years age group was $36 \%$, which is about double the average estimated prevalence of adenomas in average risk individuals of the same age in the quoted studies (15\%), whereas the prevalence in our subjects aged over 60 years was only slightly higher $(46 \cdot 2 \% v$ $35 \%)$.

Within the screened group, the higher prevalence of adenomas with increasing age and in male subjects is consistent with the data from previous studies in patients with or without a positive family history. ${ }^{6}{ }^{14-20}$ In essence, in our series the prevalence of adenomas in men was the same as the prevalence in women a decade later. This was found to be true at all ages except the youngest (25-34 years). There was no difference between the morphological features of adenomas in men and women (Tables I and II).

It is clear from Table I that adenomas are more common in individuals from HNPCC families, and other features such as multiple adenomas and right sided lesions are also

TABLE V Multivariate analysis

\begin{tabular}{|c|c|c|c|}
\hline Variable & Category & Coefficient & OR $(95 \% C I)$ \\
\hline Age (y) & $\begin{array}{l}25-34^{\star} \\
35-44 \\
45-54 \\
\geqslant 55 \\
\chi^{2} \text { trend } \\
\text { (p value) }\end{array}$ & $\begin{array}{l}0.94 \\
1.52 \\
2.28\end{array}$ & $\begin{array}{l}1 \\
2 \cdot 56(1 \cdot 36,4 \cdot 81) \\
4 \cdot 59(2 \cdot 44,8 \cdot 36) \\
9 \cdot 76(4 \cdot 96,19 \cdot 22) \\
55 \cdot 46 \\
(<0 \cdot 0001)\end{array}$ \\
\hline Sex & $\begin{array}{l}\text { Women } \\
\text { Men } \\
\chi^{2} \text { trend } \\
\text { (p value) }\end{array}$ & 0.76 & $\begin{array}{l}1 \\
2 \cdot 14(1 \cdot 44,3 \cdot 19) \\
14 \cdot 20 \\
(<0 \cdot 0002)\end{array}$ \\
\hline \multicolumn{4}{|c|}{$\begin{array}{l}\text { No of generations and } \\
\text { no of relatives }\end{array}$} \\
\hline No gen & No rels & Coefficient & OR $(95 \% C I)$ \\
\hline 2 & $\begin{array}{l}1 \\
2 \\
3+ \\
2 \\
3+ \\
\chi^{2} \text { trend } \\
\text { (p value) }\end{array}$ & $\begin{array}{r}-0.23 \\
-0.91 \\
0.38 \\
0.68\end{array}$ & $\begin{array}{l}1 \\
0.80(0.34,1.89) \\
0.40(0.11,1.54) \\
1.46(0.74,2.90) \\
1.97(1.08,3.57) \\
10 \cdot 16 \\
(0.01)\end{array}$ \\
\hline
\end{tabular}

${ }^{\star}$ Reference category; $\mathrm{OR}=$ odds ratio; $\mathrm{CI}=$ confidence interval. 
TABLE VI Observed and predicted prevalences based on the model of multivariate analysis

\begin{tabular}{|c|c|c|c|c|c|c|}
\hline $\begin{array}{l}\text { Age } \\
(y)\end{array}$ & Sex & $\begin{array}{l}\text { No } \\
\text { generations } \\
\text { CRC or Ads }\end{array}$ & $\begin{array}{l}\text { Subjects } \\
\text { screened }\end{array}$ & $\begin{array}{l}\text { Subjects } \\
\text { with } \\
A d s^{\star}\end{array}$ & $\begin{array}{l}\text { Observed } \\
\text { prevalence } \\
(\%)\end{array}$ & $\begin{array}{l}\text { Predicted } \\
\text { prevalence } \\
(\%)(95 \% \text { CI) }\end{array}$ \\
\hline $25-34$ & $\begin{array}{l}\mathrm{F} \\
\mathrm{F} \\
\mathrm{M} \\
\mathrm{M}\end{array}$ & $\begin{array}{r}1 \\
\geqslant 2 \\
1 \\
\geqslant 2\end{array}$ & $\begin{array}{l}35 \\
72 \\
14 \\
58\end{array}$ & $\begin{array}{l}3 \\
8(1) \\
1 \\
4(2 \dagger)\end{array}$ & $\begin{array}{r}8 \cdot 6 \\
11 \cdot 1 \\
7 \cdot 1 \\
6 \cdot 9\end{array}$ & $\begin{array}{c}3 \cdot 6(1 \cdot 2,6 \cdot 0) \\
7 \cdot 4(3 \cdot 4,11 \cdot 4) \\
7 \cdot 3(2 \cdot 7,11 \cdot 9) \\
14 \cdot 5(7 \cdot 5,21 \cdot 5)\end{array}$ \\
\hline $35-44$ & $\begin{array}{l}\mathbf{F} \\
\mathbf{F} \\
\mathbf{M} \\
\mathbf{M}\end{array}$ & $\begin{array}{r}1 \\
\geqslant 2 \\
1 \\
\geqslant 2\end{array}$ & $\begin{array}{l}51 \\
72 \\
33 \\
59\end{array}$ & $\begin{array}{c}4(1) \\
13(2) \\
6(1) \\
17(5+)\end{array}$ & $\begin{array}{r}7 \cdot 8 \\
18 \cdot 1 \\
18 \cdot 2 \\
28 \cdot 8\end{array}$ & $\begin{array}{l}8.6(4 \cdot 4,12 \cdot 8) \\
16.9(10 \cdot 7,23 \cdot 1) \\
16 \cdot 8(9 \cdot 4,24 \cdot 4) \\
30 \cdot 4(21 \cdot 4,39 \cdot 4)\end{array}$ \\
\hline $45-54$ & $\begin{array}{l}\mathrm{F} \\
\mathrm{F} \\
\mathrm{M}\end{array}$ & $\begin{array}{r}1 \\
\geqslant 2 \\
1 \\
\geqslant 2\end{array}$ & $\begin{array}{l}31 \\
64 \\
16 \\
46\end{array}$ & $\begin{array}{c}3(1) \\
17(3 t) \\
4(2) \\
22(5 t)\end{array}$ & $\begin{array}{r}9 \cdot 7 \\
26 \cdot 6 \\
25 \cdot 0 \\
47 \cdot 8\end{array}$ & $\begin{array}{l}14 \cdot 4(7 \cdot 6,21 \cdot 2) \\
26 \cdot 7(18 \cdot 5,34 \cdot 9) \\
26 \cdot 5(15 \cdot 7,37 \cdot 3) \\
43 \cdot 9(33 \cdot 3,54 \cdot 5)\end{array}$ \\
\hline$\geqslant 55$ & $\begin{array}{l}\mathrm{F} \\
\mathrm{F} \\
\mathrm{M} \\
\mathrm{M}\end{array}$ & $\begin{array}{l}1 \\
\geqslant 2 \\
1 \\
\geqslant 2\end{array}$ & $\begin{array}{l}19 \\
35 \\
14 \\
25\end{array}$ & $\begin{array}{l}4(3) \\
13(3 \ddagger) \\
7(2) \\
18(8)\end{array}$ & $\begin{array}{l}21 \cdot 1 \\
37 \cdot 1 \\
50 \cdot 0 \\
72 \cdot 0\end{array}$ & $\begin{array}{l}26 \cdot 4(15 \cdot 6,37 \cdot 2) \\
43 \cdot 7(31 \cdot 7,55 \cdot 7) \\
43 \cdot 4(29 \cdot 0,57 \cdot 8) \\
62 \cdot 4(50 \cdot 4,74 \cdot 4)\end{array}$ \\
\hline
\end{tabular}

$\mathrm{CRC}=$ colorectal cancer; Ads = adenomas; $\mathrm{M}=$ male; $\mathrm{F}=$ female; $\mathrm{CI}=$ confidence interval $\star$ In brackets, the number of patients with significant findings: large $(\geqslant 10 \mathrm{~mm})$, or villous/tubulovillous, or moderately/severely dysplastic adenomas or cancers (†one cancer, villous/tubulovillo analysis. When the analysis was repeated, randomly choosing one individual from each family, the number of generations affected by colorectal cancer or adenomas, or both, still emerged as the most significant variable after age and sex, with no other family history variable entering the model.

We observed an increased prevalence of adenomas in individuals from the 35 families with one affected generation represented by individuals with adenomas rather than colorectal cancer. While this might represent inheritance of an adenoma prone genotype, we cannot exclude the possibility that other factors associated with our selection process for colonoscopy (such as an increased family history of extracolonic cancers) had played a role. In nearly half $(47 \%)$ of these families there was indeed a more extensive family history of extracolonic cancers. We are currently investigating this.

The choice of criteria for offering colonoscopic surveillance is a major problem in planning a screening programme, since colonoscopy is costly (about $£ 450$ ), and carries a small but important risk of morbidity. ${ }^{24}$

If colonoscopic screening had been offered only to individuals from HNPCC families, the rate of detection of adenomas would have been less than if the screening criteria were widened to include two generation histories of colorectal cancer with or without adenomas. If screening were to have been offered to subjects from families with two or more generations affected by colorectal cancer or adenomas, about $80 \%$ of the total adenomas and all of the cancers (seven of seven) would have been detected (Table IV). If surveillance by flexible sigmoidoscopy had been offered to the individuals with a lower risk, as suggested by Rozen, ${ }^{6}$ at least 16 more subjects with adenomas would have been diagnosed, raising the overall detection rate of adenomas in our series to about $90 \%$.

All the patients with a cancer had two or more generations of relatives affected by colorectal cancer or adenomas in their family. Only one cancer had developed beyond Dukes's stage A, suggesting that screening had probably improved the outlook for disease free survival in these patients. All but one of the carcinomas found were in individuals younger than 60 years of age, and these were all in the proximal colon; only the cancer diagnosed in a 63 year old woman was sited distally. This confirms the tendency for early age of onset and right sided carcinomas in patients with a positive family history. ${ }^{25}$ In addition, in the Amsterdam criteria group, $47 \%$ of adenomas were right sided only. These points support the view that colonoscopy is the preferred method of screening individuals with a high genetic risk.

The data from this study suggest that the knowledge of the number of generations affected by colorectal cancer or adenomas may be of assistance in the planning of a family cancer screening programme. Burt et al found that a dominant Mendelian pattern of inheritance became apparent in the kindreds they in this study was not totally independent of the other variables.

The results could have been biased by the fact that in 113 families more than one individual was screened and included in the 
studied only when the occurrence of adenoma in addition to colorectal cancer was taken into account. ${ }^{2627}$ However, the value of this family history variable might often be limited by the fact that information about relatives with adenomas is not easily available where many members of the family are not under surveillance. In our series, most relatives (68\%) with adenomas were ascertained by the screening process itself (Table IV).

If the detection of adenomas in the screened population is indicative of an increased risk of colorectal cancer and can prevent cancer deaths in the long term, it may be that screening can be focused on those groups found to have a higher risk of adenomas at colonoscopy. We have actually increased the population screened to those who do not fulfil the original criteria set out by Slack. Our novel observation of the strong predictive power of having two or more generations affected by colorectal cancer or adenomas (in addition to the original screened groups) needs to be validated in other series before any recommendations based on these findings can be made.

This study was supported by Imperial Cancer Research Fund. We thank Dr V Murday and Dr J Slack for setting up the clinic initially, Dr J Sheffield for reviewing some of the histopathology from patients, Dr B De Stavola for her assistance in the statistical analysis, and Mrs C Harocopos and Mrs S Epstein for their help in collecting data and secretarial assistance.

1 Office of Population Census and Surveys. Cancer statistics. Registration. Cases of diagnosed cancer registered in England and Wales, 1986. London: HM Stationery Office, 1993. Series MB1 no 19

2 Hill MJ, Morrison BC, Bussey HJR. Aetiology of adenomacarcinoma sequence in the large bowel. Lancet 1978; i: 245-7.

3 Waye JD. Colon polyps: problems, promises, prospects. $\mathrm{Am}$ $f$ Gastroenterol 1986; 81: 101-3.

4 Winawer SJ, Zauber AG, Ho MN, O'Brien MJ, Gottlieb LS, Sternberg SS, et al. The prevention of colorectal cancer by colonoscopic polypectomy. New Engl $\mathfrak{f}$ Med 1993; 329: 2028-9.

5 Burt RW, Bishop DT, Lynch HT, Rozen P, Winawer SJ Risk and surveillance of individuals with heritable factor for colorectal cancer. Bull WHO 1990; 68: 655-65.

6 Rozen P, Fireman Z, Figer A, Legum C, Ron E, Lynch HT Family history of colorectal cancer as a marker of potential malignancy within a screening program. Cancer 1987; 60: 248-54.
7 Mecklin JP, Jarvinen HJ, Peltokallio P. Cancer family syndrome. Genetic analysis of 22 finnish kindreds. Gastroenterology 1986; 90: 328-33.

8 Lynch HT, Watson P, Kriegler M, Lynch JF, Lanspa SJ, Marcus J, et al. Differential diagnosis of heditary non polyposis colorectal cancer (Lynch syndrome I and Lynch syndrome II). Dis Colon Rectum 1988; 31: 372-7.

9 Lovett E. Family studies in cancers of the colon and rectum Brf Surg 1976; 63: 13-8.

10 Macklin MT. Inheritance of cancer of the stomach and large intestine in man. $\mathcal{F}$ Nat Cancer Inst 1960; 24: 551-71.

11 Houlston RS, Murday V, Harocopos C, Williams CB, Slack J. Screening and genetic counselling for relatives of patients with colorectal cancer in a family cancer clinic. BMF 1990; 301: 366-8.

12 International Collaborative Group on HNPCC. Dis Colon Rectum 1991; 34: 424-5.

13 Dixon WJ. BMDP-88 Biomedical Computers Programs. California: University of California Press, 1988.

14 Johnson DA, Gurney MS, Volpe RJ, Jones DM, VanNess MM, Chobanian SJ, et al. A prospective study of the prevalence of colonic neoplasms in asymtomatic patients with an age-related risk. Am $\mathcal{G}$ Gastroenterol 1990; 85: 969-74.

15 Rex DK, Lehman GA, Hawes RH, Ulbright TM, Smith J. Screening colonoscopy in asymptomatic average-risk persons with negative fecal occult blood tests. Gastroenterology 1991; 100: 64-7.

16 DiSario JA, Foutch PG, Mai HD, Pardy K, Manne RK. Prevalence and malignant potential of colorectal polyps in asymptomatic, average-risk men. Am 7 Gastroenterol 1991; 86: $941-5$.

17 McConnell JC, Nizin JS, Slade MS. Colonoscopy in patients with a primary family history of colon cancer. Dis patients with a primary family hist

18 Baker JW, Gathright Jr JB, Timmcke AE, Hicks TC, Ferrari BT, Ray JE. Colonoscopicy Screening of asymptomatic patients with a family history of colon cancer. Dis Colon Rectum 1990; 33: 926-30.

19 Sauer J, Hoff G, Hausken T, Bjorkheim A, Foerster A, Mowinckel P. Colonoscopic screening examination of relatives of patients with colorectal cancer. Scand Gastroenterol 1992; 27: 667-72.

20 Guillem JG, Forde KA, Treat MR, Neugut AI, O'Toole KM, Diamond BE. Colonoscopic screening for neoplasms in asymptomatic first-degree relatives of colon neoplasms in asymptomatic first-degree relatives of

21 Orrom WJ, Brzezinski WS, Wiens EW. Heredity and colorectal cancer. A prospective, community based, endoscopic study. Dis Colon Rectum 1990; 33: 490-3.

22 Gryska PV, Cohen AM. Screening asymptomatic patients at high risk for colon cancer with full colonoscopy. Dis Colon Rectum 1987; 30: 18-20.

23 Grossman S, Milos ML. Colonoscopic screening of persons with suspected risk factors for colon cancer. Gastroenterol 1988; 94: 395-400.

24 Macrae FA, Tan KG, Williams CB. Towards safer colonoscopy: a report on the complications of 5000 diagnostic or therapeutic colonoscopies. Gut 1983; 24: 376-83

25 Lynch PM, Lynch HT, Harris RE. Hereditary proximal colonic cancer. Dis Colon Rectum 1977; 20: 661-8.

26 Burt RW, Bishop DT, Cannon, Dowdle MA, Lee RG, Skolnick MH. Dominant inheritance of adenomatous colonic polyps and colorectal cancer. N Engl f Med 1985; 312: 1540-4.

27 Cannon-Albright LA, Skolnick MH, Bishop DT, Le RG Burt RW. Common inheritance of susceptibility to colonic adenomatous polyps and associated colorectal cancer. N Engl f Med 1988; 319: 533-7. 